\title{
Red cell distribution width as a marker of activity in inflammatory bowel disease: a narrative review
}

\author{
Marios Katsaros ${ }^{\mathrm{a}}$, Paschalis Paschos ${ }^{\mathrm{b}}$, Olga Giouleme ${ }^{\mathrm{a}}$ \\ Aristotle University of Thessaloniki, Hippokration Hospital; Papageorgiou Hospital, Thessaloniki, Greece
}

\section{Abstract}

\begin{abstract}
Red blood cell distribution width is a parameter measured automatically in every complete blood count that actually reflects the degree of anisocytosis of the red blood cell population. It is a costeffective tool used in everyday clinical practice along with other parameters to define and narrow the cause of anemia. In a series of pathologic entities, such as cardiovascular diseases, autoimmune diseases, malignancy, chronic renal diseases and chronic respiratory diseases, where inflammation and oxidative stress comprise the major pathophysiologic insults, red cell distribution width behaves as a significant and competent marker able to predict and assess disease activity and severity. A number of clinical studies based on these observations have aimed to evaluate its potential utility as an index of activity in inflammatory bowel disease. In this narrative review we present data from the international literature regarding its ability to express disease activity and we look into its relation with clinical, laboratory and endoscopic indices used to identify active disease. According to the results of published clinical trials, red cell distribution width is considerably correlated with disease activity and might serve as an index to differentiate Crohn's disease from ulcerative colitis.
\end{abstract}

Keywords Red cell distribution width, inflammatory bowel disease, Crohn's disease, ulcerative colitis, disease activity

Ann Gastroenterol 2020; 33 (4): 1-7

\section{Introduction}

Red cell distribution width (RDW) is an automatic expression of hematologic analyzers reflecting the size variability of circulating red blood cells (RBC). It is a marker used together with other laboratory parameters to determine and narrow the cause of anemia [1] and it has shown promising potential as an index of disease activity and severity in various pathologic conditions [2-6].

The diagnosis and follow up of inflammatory bowel disease (IBD) are based on a combination of clinical indices, laboratory

${ }^{\mathrm{a}}$ Gastroenterology and Hepatology Division of the Second Propedeutic Department of Internal Medicine, Medical School, Aristotle University of Thessaloniki, Hippokration Hospital (Marios Katsaros, Olga Giouleme); 'First Department of Internal Medicine, "Papageorgiou" Hospital (Paschalis Paschos), Thessaloniki, Greece

Conflict of Interest: None

Correspondence to: Marios Katsaros, Gastroenterology and Hepatology Division of the Second Propedeutic Department of Internal Medicine, Medical School, Aristotle University of Thessaloniki, Hippokration Hospital, Konstantinoupoleos 49 street, PC 54642 Thessaloniki Greece, email: markatsaros@gmail.com

Received 1 February 2020; accepted 8 March 2020; published online 10 May 2020

DOI: https://doi.org/10.20524/aog.2020.0486 markers, endoscopy, histology and imaging modalities [7,8]. However, these have various disadvantages, such as low sensitivity and specificity, high cost, limited availability, absence of simplicity, invasiveness, and lack of reproducibility $[9,10]$.

The demand for an index used to recognize and monitor disease activity in IBD that overcomes these disadvantages still remains unmet. Since RDW expresses a lot of attractive characteristics, a number of clinical studies have been performed to evaluate its application as a surrogate marker of disease activity in IBD. We searched MEDLINE and the Cochrane Library through December 2019. Search terms included "red cell distribution width", "Inflammatory bowel disease", "Crohn's Disease" and "Ulcerative Colitis", and we critically reviewed all relevant articles published in English. The intention of this review is to summarize the current state of knowledge on the utility of RDW as a marker of activity in IBD.

\section{Clinical utility of RDW}

RDW, a parameter measured automatically in every complete blood count (CBC), is an actual reflection of RBC size variability and heterogeneity. RDW is considered as a reliable index of the anisocytosis of the RBC population circulating in peripheral blood. There are 2 different ways to express RDW statistically: as a coefficient of variation (RDW-CV) and/or a standard deviation (RDW-SD). RDW-SD (expressed in $\mathrm{fL}$ ) is 
an actual evaluation of the width of the RBC size distribution histogram and is quantified after determination of the width (in $\mathrm{fL}$ ) at the $20 \%$ height level of that histogram. This index is therefore not influenced by the average size of the RBC population, the mean corpuscular volume (MCV).

On the other hand, RDW-CV (expressed in \%) is derived from a mathematical formula that includes SD and MCV:

RDW-CV $(\%)=1$ standard deviation of RBC volume / $\mathrm{MCV} \times 100 \%$

and it is affected by variations in RBC size [11]. Anemias were traditionally classified, according to their MCV value, as microcytic (MCV below the reference range), normocytic (MCV within the reference range) and macrocytic (MCV above the reference range). In the early 80 s a different approach was proposed for anemia classification using both RDW and MCV [12].

Based on this classification, 2 distinct entities of anemias were described: one with a homogeneous erythrocyte population and normal RDW, and a second with a heterogeneous erythrocyte population and a greater RDW [13]. The main conditions that influence and elevate RDW value include anemias due to nutritional deficiencies (iron, B12 and folate), hemoglobinopathies, hemolytic anemias, and sicklecell anemia [14,15] (Table 1).

Apart from its usual application as a hematologic parameter, RDW has been extensively studied as an inflammatory marker, along with its capability to express the activity and severity of various disease states and conditions. Probably the first recorded strong correlation of RDW with laboratory indices of inflammation, such as C-reactive protein (CRP) and erythrocyte sedimentation rate (ESR), came after a retrospective study of 3845 outpatient adults performed by Lippi et al [16].

Cardiovascular diseases, malignancy, chronic lower respiratory diseases, metabolic syndrome, chronic kidney disease and autoimmune disorders belong to a group of disorders where inflammation and oxidative stress comprise the major pathophysiologic insults [17-22]. Data from the international literature showed that in these clinical entities, an elevated RDW value was related to an increased risk of morbidity and mortality and could be used as a predictor of an unfavorable disease course [23-29].

Table 1 Conditions that elevate red cell distribution width [14,15]

\begin{tabular}{ll}
\hline RDW value & Elevated \\
\hline Normal MCV & $\begin{array}{l}\text { Early iron, vitamin B12, or folate deficiency } \\
\text { Sickle-cell disease } \\
\text { Myelodysplastic syndrome }\end{array}$ \\
Elevated MCV & Folate or vitamin B12 deficiency \\
& Immune hemolytic anemia \\
& Myelodysplastic syndrome \\
& Drug-induced \\
& Bone marrow disorders \\
& Hemolytic anemia \\
Decreased MCV deficiency \\
& Sickle-cell $\beta$-thalassemia \\
& Microangiopathic hemolytic anemia \\
\hline
\end{tabular}

RDW, red cell distribution width; $M C V$, mean corpuscular volume
Despite the encouraging data concerning its potential as a prognostic marker of morbidity, mortality and unfavorable disease course in various pathologic conditions, in everyday clinical practice RDW remains a parameter used to define and differentiate anemias.

\section{RDW in IBD}

There are different proposed mechanisms that attempt to explain why RDW is elevated in active IBD and how this is correlated with disease activity. The most probable encountered etiologies involve anemia, and especially iron deficiency anemia (IDA), as well as the impact of inflammation and oxidative stress on the normal process of erythropoiesis.

Anemia in IBD seems to be multifactorial, with an estimated prevalence between 9-74\%, while IDA represents the commonest type [30,31]. Causes implicated include continuous microscopic or macroscopic blood loss from the ulcerated intestinal mucosa, nutritional deficits of vitamins and minerals (iron, folate, B12) due to decreased intake or absorption, effects of medication, and inflammatory insults in the process of hematopoiesis [32]. The RDW value is directly affected and subsequently elevated in IDA, as well as in situations of B12 and folate deprivation, while it is known that the degree and severity of anemia in both Crohn's disease (CD) and ulcerative colitis (UC) are linked to disease activity $[33,34]$.

IBD are chronic and relapsing inflammatory conditions of the gastrointestinal tract. [35]. Chronic inflammation through the exertional effect of cytokines-interleukin-1, interleukin-6, tumor necrosis factor- $\alpha$, interferon- $\gamma$-may cause impaired erythropoietin (EPO) production, alterations of red blood cell life span, diminished responsiveness of bone marrow to EPO and impaired iron metabolism, disrupting the normal process of hematopoiesis [36,37]. Data from the international literature suggest that anemia in IBD is multifactorial and is considered to be a combination of IDA and anemia of chronic disease (ACD), caused by a series of negative effects of an activated immune system at different levels of erythropoiesis $[38,39]$.

The presence of RBC populations with marked heterogeneity in size, as a result of anemia and deficient erythropoiesis due to direct and indirect effects of inflammation and oxidative stress, seems to be an attractive hypothesis that can possibly explain the correlation of RDW with disease activity [40,41]. The international literature contains a rather small number of publications that aimed to investigate RDW as an index of activity in IBD, or its correlation with clinical and laboratory markers used to express active disease (Table 2).

The first study published in 2008 by Molnar et al [42] was a retrospective study, complementary to that of Clarke et al [43], that aimed to highlight any relation between RDW and disease activity. The investigators intended to clarify whether its quantitative fluctuations could be correlated with laboratory markers of inflammation and/or clinical indices of activity. They also tried to evaluate the potential of RDW to differentiate $\mathrm{CD}$ from UC in both the active state and remission. Mean values of RDW were significantly elevated in the active form 
Table 2 Published studies/clinical trials evaluating the role of red cell distribution width as a marker of activity in inflammatory bowel diseases

\begin{tabular}{|c|c|c|c|c|c|c|c|c|}
\hline Reference & $\begin{array}{l}\text { Type of } \\
\text { study }\end{array}$ & Study group & $\begin{array}{l}\text { Clinical } \\
\text { activity } \\
\text { index }\end{array}$ & $\begin{array}{l}\text { Endoscopic } \\
\text { activity } \\
\text { index }\end{array}$ & $\begin{array}{l}\text { Laboratory } \\
\text { parameters }\end{array}$ & $\begin{array}{l}\text { RDW } \\
\text { cut-off }\end{array}$ & $\begin{array}{l}\text { Sensitivity } \\
\text { Specificity }\end{array}$ & Primary aim \\
\hline $\begin{array}{l}\text { Molnar et al } \\
{[42]}\end{array}$ & Retrospective & $\begin{array}{l}92 \mathrm{CD} / 84 \\
\mathrm{UC}\end{array}$ & CDAI & & CRP, ESR, Fe & $\begin{array}{l}>14 \% \text { in } \\
\mathrm{CD} / \mathrm{UC}\end{array}$ & & $\begin{array}{l}\text { RDW correlation } \\
\text { with CDAI, ESR, } \\
\text { CRP in active } \\
\text { and inactive CD/ } \\
\text { UC - RDW ability } \\
\text { to differentiate CD } \\
\text { from UC }\end{array}$ \\
\hline Cakal et al [44] & $\begin{array}{l}\text { Cross- } \\
\text { sectional }\end{array}$ & $\begin{array}{l}22 \mathrm{CD} / \\
74 \mathrm{UC} / \\
20 \text { matched } \\
\text { controls }\end{array}$ & $\begin{array}{l}\text { CDAI/ } \\
\text { Truelove- } \\
\text { Witts }\end{array}$ & & $\begin{array}{l}\text { fibrinogen, } \\
\text { CRP, ESR, } \\
\text { WBC, PLT }\end{array}$ & $\begin{array}{l}14 \% \mathrm{UC} \\
14,1 \% \mathrm{CD}\end{array}$ & $\begin{array}{l}88-71 \% / \mathrm{UC} \\
78-63 \% / \mathrm{CD} \\
\text { to detect } \\
\text { active disease }\end{array}$ & $\begin{array}{l}\text { RDW potential to } \\
\text { detect active disease }\end{array}$ \\
\hline $\begin{array}{l}\text { Oustamanolakis } \\
\text { et al [45] }\end{array}$ & $\begin{array}{l}\text { Cross- } \\
\text { sectional }\end{array}$ & $\begin{array}{l}51 \mathrm{CD} / \\
49 \mathrm{UC} / \\
102 \text { matched } \\
\text { controls }\end{array}$ & $\begin{array}{l}\text { CDAI / } \\
\text { SCCAI }\end{array}$ & & $\begin{array}{l}\text { CBC, RSF, IRF, } \\
\text { RDWR-SD, } \\
\text { RDWR-CV,ESR, } \\
\text { CRP,Fe, Fer, } \\
\text { TRF, sTfR, Tsat }\end{array}$ & $14 \%$ & $\begin{array}{l}93-84 \% \text { for } \\
\text { diagnosis of } \\
\text { IDA }\end{array}$ & $\begin{array}{l}\text { Use of reticulocyte } \\
\text { and RBC indices in } \\
\text { the evaluation of } \\
\text { anemia }\end{array}$ \\
\hline Arhan et al [46] & Retrospective & $\begin{array}{l}60 \mathrm{CD} / \\
105 \mathrm{UC} / \\
43 \text { healthy } \\
\text { blood donors }\end{array}$ & $\begin{array}{l}\text { CDAI/ } \\
\text { Truelove- } \\
\text { Witts }\end{array}$ & $\begin{array}{l}\text { EAI for } \\
\text { UC }\end{array}$ & $\begin{array}{l}\text { Hb, Hct, WBC, } \\
\text { PLT, ESR, CRP }\end{array}$ & $14,45 \%$ & $\begin{array}{l}70-56 \% \text { to } \\
\text { differentiate } \\
\text { CD from UC }\end{array}$ & $\begin{array}{l}\text { RDW potential to } \\
\text { detect active disease }\end{array}$ \\
\hline Yesil et al [47] & $\begin{array}{l}\text { Cross- } \\
\text { sectional }\end{array}$ & $\begin{array}{l}56 \mathrm{CD} / \\
61 \mathrm{UC} / \\
44 \mathrm{matched} \\
\text { controls }\end{array}$ & $\begin{array}{l}\text { CDAI/ } \\
\text { Truelove- } \\
\text { Witts }\end{array}$ & & $\begin{array}{l}\text { Hb, Hct, WBC, } \\
\text { PLT, ESR, CRP }\end{array}$ & $\begin{array}{l}14 \% \mathrm{UC} \\
14 \% \mathrm{CD}\end{array}$ & $\begin{array}{l}17-84 \% \text { to } \\
\text { detect active } \\
\text { UC } \\
73-86 \% \text { to } \\
\text { detect active } \\
\text { CD }\end{array}$ & $\begin{array}{l}\text { RDW as marker of } \\
\text { activity }\end{array}$ \\
\hline Song et al [48] & Retrospective & $\begin{array}{l}101 \mathrm{CD}-120 \\
\mathrm{UC}\end{array}$ & $\begin{array}{l}\text { CDAI / } \\
\text { Mayo score }\end{array}$ & & $\begin{array}{l}\text { Hb, Hct, WBC, } \\
\text { PLT, ESR, CRP }\end{array}$ & $\begin{array}{l}13,8 \% \text { non- } \\
\text { anemic UC } \\
14,1 \% \text { non- } \\
\text { anemic } \\
\text { CD }\end{array}$ & $\begin{array}{l}76-86 \% \\
\text { to detect } \\
\text { active UC } \\
82-86 \% \\
\text { to detect } \\
\text { active CD }\end{array}$ & $\begin{array}{l}\text { RDW as marker } \\
\text { of activity in both } \\
\text { anemic/non anemic } \\
\text { patients }\end{array}$ \\
\hline $\begin{array}{l}\text { Voudoukis } \\
\text { et al [49] }\end{array}$ & $\begin{array}{l}\text { Cross- } \\
\text { sectional }\end{array}$ & $\begin{array}{l}107 \mathrm{CD}- \\
91 \mathrm{UC} / \\
/ 102 \text { controls }\end{array}$ & $\begin{array}{l}\text { CDAI/ } \\
\text { SCCAI }\end{array}$ & & $\begin{array}{l}\text { Hb, Hct,MCV, } \\
\text { RDW, } \\
\text { PLT,MPV, } \\
\text { PDW, PCT, } \\
\text { sTfR, sTfR-F } \\
\text { index, B12, } \\
\text { folate }\end{array}$ & & & $\begin{array}{l}\text { Platelet parameters } \\
\text { (PLT,PCT,PDW, } \\
\text { MPV), in IBD } \\
\text { patients in } \\
\text { comparison with } \\
\text { healthy controls/ } \\
\text { correlation between } \\
\text { platelet parameters } \\
\text { and RBC and } \\
\text { anemia indices }\end{array}$ \\
\hline $\begin{array}{l}\text { Huang } \\
\text { et al [50] }\end{array}$ & Retrospective & $\begin{array}{l}68 \mathrm{CD} / \\
35 \text { Intestinal } \\
\text { tuberculosis } \\
\text { / } 22 \text { irritable } \\
\text { bowel } \\
\text { syndrome }\end{array}$ & $\begin{array}{l}\text { Harvey- } \\
\text { Bradshaw } \\
\text { index }\end{array}$ & & $\begin{array}{l}\text { CRP, ESR, RBC, } \\
\text { WBC, PLT, } \\
\text { MPV and RDW }\end{array}$ & & & $\begin{array}{l}\text { Diagnostic utility } \\
\text { of RDW, PLT and } \\
\text { MPV in active } \\
\text { CD and intestinal } \\
\text { tuberculosis }\end{array}$ \\
\hline Ipek et al [51] & Retrospective & $\begin{array}{l}310 \text { UC / } \\
206 \text { active, } \\
104 \\
\text { remission }\end{array}$ & & $\begin{array}{l}\text { Rachmilewitz } \\
\text { activity index }\end{array}$ & CBC, ESR, CRP & $16.66 \%$ & $\begin{array}{l}41-91 \% \\
\text { to detect } \\
\text { disease } \\
\text { activity }\end{array}$ & $\begin{array}{l}\text { Association between } \\
\text { RDW levels and } \\
\text { disease activity - } \\
\text { RDW as an index } \\
\text { of disease activity } \\
\text { in non-anemic UC } \\
\text { patients }\end{array}$ \\
\hline
\end{tabular}


Table 2 (Continued)

\begin{tabular}{|c|c|c|c|c|c|c|c|c|}
\hline Reference & $\begin{array}{l}\text { Type of } \\
\text { study }\end{array}$ & Study group & $\begin{array}{l}\text { Clinical } \\
\text { activity } \\
\text { index }\end{array}$ & $\begin{array}{l}\text { Endoscopic } \\
\text { activity } \\
\text { index }\end{array}$ & $\begin{array}{l}\text { Laboratory } \\
\text { parameters }\end{array}$ & $\begin{array}{l}\text { RDW } \\
\text { cut-off }\end{array}$ & $\begin{array}{l}\text { Sensitivity } \\
\text { Specificity }\end{array}$ & Primary aim \\
\hline $\begin{array}{l}\text { Oliveira } \\
\text { et al [52] }\end{array}$ & $\begin{array}{l}\text { Cross- } \\
\text { sectional }\end{array}$ & $119 \mathrm{CD}$ & CDAI & & $\begin{array}{l}\text { CRP, ESR, PLT, } \\
\text { WBC, Hb, } \\
\text { MCV }\end{array}$ & $16 \%$ & $\begin{array}{l}30-88 \% \\
\text { to detect } \\
\text { disease } \\
\text { activity }\end{array}$ & $\begin{array}{l}\text { RDW as a marker of } \\
\text { CD activity }\end{array}$ \\
\hline Hu et al [53] & Prospective & $\begin{array}{l}100 \mathrm{CD} / \\
102 \text { matched } \\
\text { controls }\end{array}$ & CDAI & & CBC, ESR, CRP & $15,6 \%$ & $\begin{array}{l}96.2-54.3 \% \\
\text { to detect } \\
\text { disease } \\
\text { activity }\end{array}$ & $\begin{array}{l}\text { Ability of RDW } \\
\text { to assess disease } \\
\text { activity in CD }\end{array}$ \\
\hline $\begin{array}{l}\text { Akkermans } \\
\text { et al [54] }\end{array}$ & $\begin{array}{l}\text { Cross- } \\
\text { sectional }\end{array}$ & $\begin{array}{l}42 \mathrm{CD} / \\
14 \mathrm{UC} / 3 \\
\text { unclassified }\end{array}$ & $\begin{array}{l}\text { PCDAI/ } \\
\text { PUCAI }\end{array}$ & & $\begin{array}{l}\text { PMV, } \\
\text { RDW, ZPP, } \\
\text { Reticulocytes }\end{array}$ & & & $\begin{array}{l}\text { ZPP and RDW } \\
\text { as biomarkers of } \\
\text { iron restricted } \\
\text { erythropoiesis } \\
\text { in pediatric IBD } \\
\text { patients }\end{array}$ \\
\hline Goyal et al [55] & Review & $\begin{array}{l}8 \text { studies } \\
\text { including } \\
\text { CD / UC } \\
\text { patients / } \\
\text { matched } \\
\text { controls }\end{array}$ & $\begin{array}{l}\text { CDAI / } \\
\text { Truelove- } \\
\text { Witts / } \\
\text { Mayo score }\end{array}$ & $\begin{array}{l}\text { Rachmilewitz } \\
\text { activity index }\end{array}$ & $\begin{array}{l}\text { CBC, RSF, } \\
\text { IRF, RDWR- } \\
\text { SD, RDWR- } \\
\text { CV,ESR, CRP, } \\
\text { Fe, Fer, TRF, } \\
\text { sTfR, Tsat, ESR, } \\
\text { CRP }\end{array}$ & $\begin{array}{l}\text { Different } \\
\text { among } \\
\text { studies } \\
\text { included }\end{array}$ & $\begin{array}{l}\text { Different } \\
\text { among } \\
\text { studies } \\
\text { included }\end{array}$ & $\begin{array}{l}\text { RDW was evaluated } \\
\text { in IBD as an } \\
\text { index of disease } \\
\text { activity / marker } \\
\text { to differentiate CD } \\
\text { from UC / index } \\
\text { to evaluate anemia } \\
\text { in IBD }\end{array}$ \\
\hline
\end{tabular}

CD, Crohn's disease; UC, ulcerative colitis; CDAI, Crohn's disease activity index; SCCAI, simple clinical colitis activity index; EAI, endoscopic activity index; CBC, complete blood count; WBC, white blood cells; RBC, red blood cells; PLT, platelets; Hb, hemoglobin; Hct, hematocrit; MCV, mean corpuscular volume; $M P V$, mean platelet volume; $C R P, C$-reactive protein; $E S R$, erythrocyte sedimentation rate; RDW, red cell distribution width; RSF, red blood cell size factor; IRF, immature reticulocyte fraction; $R D W R-C V$, reticulocyte distribution width coefficient of variation; $R D W R-S D$, reticulocyte distribution widthstandard deviation; Tsat, transferrin saturation; sTfR, soluble transferrin receptor; Fe, serum iron; Fer, Ferritin; IDA, iron deficiency anemia; PDW, platelet distribution width; PCT, plateletcrit; B12, vitamin B12; PCDAI, pediatric Crohn's disease activity index; PUCAI, pediatric ulcerative colitis activityindex; $Z P P$, zincprotoporphyrin

of both CD and UC and also in inactive CD cases compared to the normal values of RDW (RDW 11-14\%). The authors concluded that RDW could be used as an additional marker able to express active disease, based on the fact that its value was remarkably related to clinical activity indices.

Cakal et al [44] performed a cross-sectional study with primary outcome the evaluation of RDW's potential in the assessment of active disease in IBD patients. In patients with active disease, laboratory indices (RDW, fibrinogen, CRP, ESR, and platelet [PLT] counts) had significantly higher values compared to those with inactive disease and controls $(\mathrm{P}<0.05)$. RDW was the most sensitive and specific parameter indicating active disease in patients with UC. In CD patients, CRP at a cutoff of $0.54 \mathrm{mg} / \mathrm{dL}$ was the most accurate parameter in the diagnosis of active disease: sensitivity $92 \%$, specificity $63 \%$ (area under the curve 0.92, $\mathrm{P}=0.001$ ).

Oustamanolakis et al [45] performed a cross-sectional study to investigate the usefulness of $\mathrm{RBC}$ and reticulocyte indices in the evaluation of anemia in IBD patients. Activity was evaluated using the Crohn's disease activity index along with the Simple Clinical Colitis Activity Index (SCCAI) and CRP. The study's results showed that RDW behaved as an accurate diagnostic marker of IDA. Despite the observation that RDW was elevated in the IBD group compared to healthy controls, there were no significant discrepancies between active and inactive disease, while no important correlation with CRP was found.

Arhan et al [46] conducted a retrospective study to determine whether RDW could be used for the assessment of disease activity in patients with IBD. RDW, ESR, CRP and PLT were all significantly increased in the patient group compared to the controls $(\mathrm{P}<0.05)$. A greater proportion of $\mathrm{CD}$ patients than of UC patients experienced higher values of RDW $(\mathrm{P}<0.05)$. There was significant correlation of RDW with ESR, PLT and endoscopic activity index in UC patients, but active disease was not correlated with an elevated RDW in either CD or UC patients.

A cross sectional study performed by Yesil et al [47] aimed to evaluate RDW as a marker of active disease in IBD patients. RDW was significantly higher in patients with CD and UC than in controls. A subsequent subgroup analysis indicated that RDW was the most sensitive and specific marker for active $\mathrm{CD}$. On the other hand, in the UC group, ESR at a cutoff of 15.5 expressed the highest sensitivity and specificity for detecting active disease.

Song et al [48] tried to evaluate the performance of RDW as a marker of disease activity in both anemic and non-anemic IBD patients. It appeared that, in both groups, CRP, ESR and RDW values increased in association with disease activity, while hemoglobin $(\mathrm{Hb})$ and hematocrit decreased (all $\mathrm{P}<0.05)$. Multivariate statistical analysis indicated that RDW was the 
most accurate independent indicator capable of predicting disease activity in non-anemic CD and UC patients. The authors concluded that RDW, at different cutoff values, was the most sensitive and specific marker of active disease in nonanemic CD and UC patients.

Voudoukis et al [49] performed a study whose primary objectives were the evaluation of PLT parameters-PLT, plateletcrit, platelet distribution width, mean PLT volume (MPV) - in IBD patients in comparison with healthy controls, as well as the investigation of any possible correlation between these parameters and RBC and anemia indices. Among the hematological and laboratory parameters examined, RDW was significantly greater in both CD and UC patients than in healthy controls, while an independent correlation was observed between RDW and thrombocytosis. The authors commented that in their study thrombocytosis appeared to be a consequence of iron deficiency, rather than a result of systemic inflammation.

A retrospective study from Huang et al [50] estimated the diagnostic utility of RDW as well as PLT and MPV in patients with active CD and intestinal tuberculosis. Results from binary logistic regression analysis showed that RDW was a more reliable independent marker in predicting active CD, compared to CRP and ESR. A retrospective study by Ipek et al [51] aimed to look into the association between RDW levels and disease activity and to investigate whether RDW can be used as an index of disease activity in non-anemic UC patients. The mean value of RDW was significantly higher in patients with active UC compared to those in remission. RDW was highly correlated with CRP, WBC, and PLT levels, but not with ESR. However, RDW was the weakest marker of disease activity in non-anemic patients.

Oliveira et al [52] investigated whether RDW can be used as a marker of CD activity. The authors noticed a significant correlation between RDW and disease activity $(\mathrm{P}=0.044)$, an association that remained strong and independent even after adjustment for Hb, ESR and biologic therapy. They concluded that, at a cutoff of $16 \%$, RDW could be possibly used as a marker of disease activity.

Hu et al [53] conducted a prospective study looking for the ability of RDW to assess disease activity in CD. RDW appeared to be significantly higher in active than in inactive $\mathrm{CD}(\mathrm{P}<0.05)$. At a given cutoff value, RDW performed better compared to ESR and WBC but worse than CRP in distinguishing active from inactive $\mathrm{CD}$.

A cross-sectional Dutch study performed by Akkermans et al [54] aimed to determine the prevalence of and potential risk factors for absolute and functional iron deficiency (ID) in

Table 3 Results of red cell distribution width as marker of activity

\begin{tabular}{|c|c|}
\hline Reference & Major findings concerning RDW \\
\hline Molnar et al [42] & $\begin{array}{l}\text { Mean RDW significantly increased in both active and inactive CD/UC } \\
\text { RDW can be used to differentiate inactive CD from UC / RDW significantly correlated with low Fe in CD / RDW } \\
\text { significantly correlated with Fe, CRP, ESR in UC in remission }\end{array}$ \\
\hline Cakal et al [44] & RDW was the most sensitive and specific index to detect active UC \\
\hline Oustamanolakis et al [45] & $\begin{array}{l}\text { Elevated RDW with low RSF were the best markers to diagnose IDA } \\
\text { No significant correlation between RDW and disease activity }\end{array}$ \\
\hline Arhan et al [46] & RDW increased in patient group / RDW correlated with ESR, PLT and EAI in UC patients \\
\hline Yesil et al [47] & RDW higher in patient group $(\mathrm{P}<0.05)$ Most sensitive and specific marker for active $\mathrm{CD}$ \\
\hline Song et al [48] & $\begin{array}{l}\mathrm{RDW} \text { is the best predictor/marker of disease activity in non-anemic CD (OR } 1.702,95 \% \mathrm{CI} 1.185-2.445 ; \mathrm{P}=0.004) \\
\text { and UC patients (OR } 4.921,95 \% \mathrm{CI} 2.281-10.615 ; \mathrm{P}<0.001) .\end{array}$ \\
\hline Voudoukis et al [49] & $\begin{array}{l}\text { RDW was significantly elevated }(\mathrm{P}<0.0001) \text { in both } \mathrm{CD}[16.1(14.8-18.1)] \text { and } \mathrm{UC}[15.7(14.6-16.7)] \text { patients than } \\
\text { in healthy controls }[13.6(12.9-14.4)] / \text { independent correlation between RDW and thrombocytosis }\end{array}$ \\
\hline Huang et al [50] & $\begin{array}{l}\text { RDW is a favorable independent marker (OR } 2.390,95 \% \text { CI } 1.269-4.502 ; \mathrm{P}=0.007) \text { in predicting active CD } \\
\text { compared to CRP (OR 1.025, 95\%CI } 0.989-1.063 ; \mathrm{P}=0.177) \text { and } \mathrm{ESR}(\mathrm{OR} 1.157,95 \% \mathrm{CI} 1.003-1.336 ; \mathrm{P}=0.046)\end{array}$ \\
\hline Ipek et al [51] & $\begin{array}{l}\text { Mean RDW }(16.8 \pm 2.9 \text { and } 15.5 \pm 1.4 \text {, respectively, } \mathrm{P}<0.001) \text { significantly elevated in active compared to inactive } \\
\text { disease and strongly correlated with } C R P(P=0.001) \text {, WBC }(\mathrm{P}=0.001) \text { and } \mathrm{PLT}(\mathrm{P}<0.001) \text {, but not } \mathrm{ESR}(\mathrm{P}=0.756) \\
\text { In anemic patients, no difference between non-anemic active and remission group }\end{array}$ \\
\hline Oliveira et al [52] & $\begin{array}{l}\text { RDW significantly related with disease activity / CDAI even after adjustment for Hb, ESR and biologic therapy } \\
(\mathrm{P}=0.01, \mathrm{P}<0.017 \text {, respectively })\end{array}$ \\
\hline Hu et al [53] & $\begin{array}{l}\text { RDW significantly higher in active CD. RDW performed better than ESR, WBC but not CRP } \\
\text { to detect active CD (overall accuracy } 76 \%, 68 \%, 51 \% \text { and } 78 \% \text { respectively) }\end{array}$ \\
\hline Akkermans et al [54] & $\begin{array}{l}\text { RDW significantly correlated with functional [RDW: } 13.8(13.0 ; 14.5) \mathrm{P}=0.006 \text { ] and absolute ID [RDW: } 15.3 \\
(14.3 ; 18.2), \mathrm{P}<0.05]\end{array}$ \\
\hline Goyal et al [55] & RDW showed promising potential as an index of disease activity as well as a marker able to differentiate CD from UC \\
\hline
\end{tabular}

CD, Crohn's disease; UC, ulcerative colitis; CDAI, Crohn's disease activity index; EAI, endoscopic activity index; OR odds ratio; CI confidence interval; WBC, white blood cells; PLT, platelets; CRP, C-reactive protein; ESR, erythrocyte sedimentation rate; RDW, red cell distribution width; RSF, red blood cell size factor; IDA, iron deficiency anemia; ID, iron deficiency 
pediatric IBD patients, using zinc protoporphyrin and RDW as biomarkers of iron-restricted erythropoiesis. Functional ID is the result of the impact of inflammation on the normal process of hematopoiesis and differs from absolute ID, caused by iron malabsorption, reduced dietary intake and continuous blood loss. The authors reported a statistically significantly correlation of RDW with functional as well as with absolute ID, along with IDA and ACD, suggesting that RDW can be used to evaluate iron-restricted erythropoiesis.

Finally, Goyal et al [55] performed a systematic review of the international literature to evaluate the prognostic value of RDW for assessment of disease severity and clinical consequences in both benign and malignant gastrointestinal disorders. The authors included in this review 8 studies where RDW was evaluated in IBD as an index of disease activity, as a marker to differentiate CD from UC, and as an index to evaluate anemia in IBD. They concluded that RDW showed promising potential as an index of disease activity as well as a marker able to differentiate CD from UC. The results of the aforementioned studies indicate the promising potential of RDW as a surrogate marker of disease activity in IBD (Table 3 ).

\section{Concluding remarks}

The results from studies included in this review showed that mean values of RDW were statistically significantly higher in IBD patients compared to controls. With respect to the rather limited data, based on only 2 clinical trials, RDW could be used as an effective marker to differentiate CD from $\mathrm{UC}$ in both the active state and remission. In the majority of the aforementioned studies RDW, at different cutoff values, showed a remarkable sensitivity and specificity in detecting active disease, calculated by means of clinical indices, endoscopic scores and laboratory parameters. RDW also showed a positive but variable correlation with well-established inflammatory biomarkers used in everyday clinical practice such as CRP, ESR, and to a lesser extent WBC and PLT, in both anemic and non-anemic IBD patients. Therefore, RDW could be considered an attractive disease activity marker in IBD, as it is calculated automatically in every CBC, has a low cost, is minimally invasive, has no specific technical requirements and can be easily reproduced.

On the other hand, there are certain aspects concerning its broad application that must be elucidated. There was great variability in the thresholds adopted for the assessment of diagnostic accuracy. In addition, the selection of cutoffs was arbitrary and data driven. Most studies were retrospective and were case-control studies. The use of controls in diagnostic accuracy studies usually results in overestimation of both sensitivity and specificity. Large-scale well-designed prospective studies for standardization of the cutoff value of RDW should now be mandatory. It is also necessary to conduct such studies in order to evaluate whether the limited but rather encouraging data are sufficient to establish RDW as a reliable activity index. Finally, there is a need to look deeper and clarify the pathophysiology of this relation. RDW seems to be a promising cost-effective tool that can be used to evaluate and monitor disease activity in IBD, but this requires more extensive and detailed research in the future.

\section{References}

1. Lippi G, Plebani M. Red blood cell distribution width (RDW) and human pathology. One size fits all. Clin Chem Lab Med 2014;52:1247-1249.

2. Kim CH, Park JT, Kim EJ, et al. An increase in red blood cell distribution width from baseline predicts mortality in patients with severe sepsis or septic shock. Crit Care 2013;17:R282.

3. Ephrem G, Kanei Y. Elevated red blood cell distribution width is associated with higher recourse to coronary artery bypass graft. Cardiology 2012;123:135-141.

4. Kim HM, Kim BS, Cho YK, et al. Elevated red cell distribution width is associated with advanced fibrosis in NAFLD. Clin Mol Hepatol 2013;19:258-265.

5. He Y, Liu C, Zeng Z, Ye W, Lin J, Ou Q. Red blood cell distribution width: a potential laboratory parameter for monitoring inflammation in rheumatoid arthritis. Clin Rheumatol 2018;37:161-167.

6. Wang H, Wang J, Huang R, et al. Red blood cell distribution width for predicting significant liver inflammation in patients with autoimmune hepatitis. Eur $J$ Gastroenterol Hepatol 2019;31:1527-1532.

7. Maaser C, Sturm A, Vavricka SR, et al; European Crohn's and Colitis Organisation [ECCO] and the European Society of Gastrointestinal and Abdominal Radiology [ESGAR]. ECCOESGAR Guideline for Diagnostic Assessment in IBD Part 1: Initial diagnosis, monitoring of known IBD, detection of complications. J Crohns Colitis 2019;13:144-164.

8. Sturm A, Maaser C, Calabrese E, et al; European Crohn's and Colitis Organisation [ECCO] and the European Society of Gastrointestinal and Abdominal Radiology [ESGAR]. ECCOESGAR Guideline for Diagnostic Assessment in IBD Part 2: IBD scores and general principles and technical aspects. J Crohns Colitis 2019;13:273-284.

9. Vucelic B. Inflammatory bowel diseases: controversies in the use of diagnostic procedures. Dig Dis 2009;27:269-277.

10. Vermeire S, Van Assche G, Rutgeerts P. Laboratory markers in IBD: useful, magic, or unnecessary toys? Gut 2006;55:426-431.

11. Constantino BT. Red cell distribution width, revisited. Lab Med 2013;44:e2-e9.

12. Bessman JD, Gilmer PR Jr, Gardner FH. Improved classification of anemias by MCV and RDW. Am J Clin Pathol 1983;80:322-326.

13. Buttarello M, Plebani M. Automated blood cell counts: state of the art. Am J Clin Pathol 2008;130:104-116.

14. Tefferi A, Hanson CA, Inwards DJ. How to interpret and pursue an abnormal complete blood cell count in adults. Mayo Clin Proc 2005;80:923-936.

15. Salvagno GL, Sanchis-Gomar F, Picanza A, Lippi G. Red blood cell distribution width: A simple parameter with multiple clinical applications. Crit Rev Clin Lab Sci 2015;52:86-105.

16. Lippi G, Targher G, Montagnana M, Salvagno GL, Zoppini G, Guidi GC. Relation between red blood cell distribution width and inflammatory biomarkers in a large cohort of unselected outpatients. Arch Pathol Lab Med 2009;133:628-632.

17. Libby P. Inflammation in atherosclerosis. Nature 2002;420:868-874.

18. Crusz SM, Balkwill FR. Inflammation and cancer: advances and new agents. Nat Rev Clin Oncol 2015;12:584-596.

19. Brody JS, Spira A. State of the art. Chronic obstructive pulmonary disease, inflammation, and lung cancer. Proc Am Thorac Soc 
2006;3:535-537.

20. Dallmeier D, Larson MG, Vasan RS, et al. Metabolic syndrome and inflammatory biomarkers: a community-based cross-sectional study at the Framingham Heart Study. Diabetol Metab Syndr 2012;4:28.

21. Cobo G, Lindholm B, Stenvinkel P. Chronic inflammation in end-stage renal disease and dialysis. Nephrol Dial Transplant 2018;33:iii35-iii40.

22. Pathak S, McDermott MF, Savic S. Autoinflammatory diseases: update on classification diagnosis and management. J Clin Pathol 2017;70:1-8.

23. Perlstein TS, Weuve J, Pfeffer MA, Beckman JA. Red blood cell distribution width and mortality risk in a community-based prospective cohort. Arch Intern Med 2009;169:588-594.

24. Zhang T, Li J, Lin Y, Yang H, Cao S. Association between red blood cell distribution width and all-cause mortality in chronic kidney disease patients: a systematic review and meta-analysis. Arch Med Res 2017;48:378-385.

25. Felker GM, Allen LA, Pocock SJ, et al; CHARM Investigators. Red cell distribution width as a novel prognostic marker in heart failure: data from the CHARM Program and the Duke Databank. $J$ Am Coll Cardiol 2007;50:40-47.

26. Sánchez-Chaparro MA, Calvo-Bonacho E, González-Quintela A, et al; Ibermutuamur CArdiovascular RIsk Assessment Study Group. Higher red blood cell distribution width is associated with the metabolic syndrome: results of the Ibermutuamur CArdiovascular RIsk assessment study. Diabetes Care 2010;33:e40.

27. Hu L, Li M, Ding $\mathrm{Y}$, et al. Prognostic value of RDW in cancers: a systematic review and meta-analysis. Oncotarget 2017;8:16027-16035.

28. Hu ZD. Red blood cell distribution width: a promising index for estimating activity of autoimmune disease. J Lab Precis Med 2016; 1:4

29. Sevinc C, Tertemiz KC, Alpaydin AO, Ellidokuz H, Acara C, Cimrin AH. Correlation between red cell distribution width and disease severity and mortality in COPD patients. Eur Respir J 2014;44:P520.

30. Wilson A, Reyes E, Ofman J. Prevalence and outcomes of anemia in inflammatory bowel disease: a systematic review of the literature. Am J Med 2004;116 Suppl 7A:44S-49S.

31. Kulnigg S, Gasche C. Systematic review: managing anaemia in Crohn's disease. Aliment Pharmacol Ther 2006;24:1507-1523.

32. Gomollón F, Gisbert JP. Anemia and inflammatory bowel diseases. World J Gastroenterol 2009;15:4659-4665.

33. Semrin G, Fishman DS, Bousvaros A, et al. Impaired intestinal iron absorption in Crohn's disease correlates with disease activity and markers of inflammation. Inflamm Bowel Dis 2006;12:1101-1106.

34. de Silva AD, Mylonaki M, Rampton DS. Oral iron therapy in inflammatory bowel disease: usage, tolerance, and efficacy. Inflamm Bowel Dis 2003;9:316-320.

35. Zhang YZ, Li YY. Inflammatory bowel disease: pathogenesis. World J Gastroenterol 2014;20:91-99.

36. Weiss G, Goodnough LT. Anemia of chronic disease. N Engl J Med 2005;352:1011-1023.

37. Price EA, Schrier SL. Unexplained aspects of anemia of inflammation. Adv Hematol 2010;2010:508739.

38. Weiss G, Gasche C. Pathogenesis and treatment of anemia in inflammatory bowel disease. Haematologica 2010;95:175-178.

39. Guagnozzi D, Lucendo AJ. Anemia in inflammatory bowel disease: a neglected issue with relevant effects. World $J$ Gastroenterol 2014;20:3542-3551.

40. Lippi G, Mattiuzzi C, Cervellin G. Learning more and spending less with neglected laboratory parameters: the paradigmatic case of red blood cell distribution width. Acta Biomed 2016;87:323-328.

41. Zurauskaite G, Meier M, Voegeli A, et al. Biological pathways underlying the association of red cell distribution width and adverse clinical outcome: Results of a prospective cohort study. PLoS One 2018;13:e191280.

42. Molnar T, Farkas K, Szepes Z, Nagy F, Nyari T, Wittmann T. RDW can be a useful additional marker in diagnosing Crohn's disease and ulcerative colitis. Dig Dis Sci 2008;53:2828-2829.

43. Clarke K, Sagunarthy R, Kansal S. RDW as an additional marker in inflammatory bowel disease/undifferentiated colitis. Dig Dis Sci 2008;53:2521-2523.

44. Cakal B, Akoz AG, Ustundag Y, Yalinkilic M, Ulker A, Ankarali H. Red cell distribution width for assessment of activity of inflammatory bowel disease. Dig Dis Sci 2009;54:842-847.

45. Oustamanolakis P, Koutroubakis IE, Messaritakis I, Kefalogiannis G, Niniraki M, Kouroumalis EA. Measurement of reticulocyte and red blood cell indices in the evaluation of anemia in inflammatory bowel disease. J Crohns Colitis 2011;5:295-300.

46. Arhan M, Önal IK, Taş A, et al. The role of red cell distribution width as a marker in inflammatory bowel disease. Turk J Med Sci 2011;41:227-234.

47. Yeşil A, Senateş E, Bayoğlu IV, Erdem ED, Demirtunç R, Kurdaş Övünç AO. Red cell distribution width: a novel marker of activity in inflammatory bowel disease. Gut Liver 2011;5:460-467.

48. Song CS, Park DI, Yoon MY, et al. Association between red cell distribution width and disease activity in patients with inflammatory bowel disease. Dig Dis Sci 2012;57:1033-1038.

49. Voudoukis E, Karmiris K, Oustamanolakis P, et al. Association between thrombocytosis and iron deficiency anemia in inflammatory bowel disease. Eur $J$ Gastroenterol Hepatol 2013;25:1212-1216.

50. Huang S, Yi FM, Zhou R, et al. The utility of platelet, mean platelet volume, and red cell distribution width in the diagnosis of active Crohn's disease and intestinal tuberculosis. Saudi Med J 2013;34:1161-1166.

51. Ipek S, Cekic C, Alper E, et al. Can red cell distribution width be a marker of disease activity in ulcerative colitis? Int J Clin Exp Med 2015;8:13848-13853.

52. Oliveira AM, Cardoso FS, Rodrigues CG, et al. Can red cell distribution width be used as a marker of Crohn's disease activity? GE Port J Gastroenterol 2015;23:6-12.

53. Hu D, Ren J, Wang G, et al. Value of red cell distribution width for assessing disease activity in Crohn's disease. Am J Med Sci 2015;349:42-45.

54. Akkermans MD, Vreugdenhil M, Hendriks DM, et al. Iron deficiency in inflammatory bowel disease: the use of zinc protoporphyrin and red blood cell distribution width. $J$ Pediatr Gastroenterol Nutr 2017;64:949-954.

55. Goyal H, Lippi G, Gjymishka A, John B, Chhabra R, May E. Prognostic significance of red blood cell distribution width in gastrointestinal disorders. World J Gastroenterol 2017;23:4879-4891. 